\title{
Teleprinter Device
}

National Cancer Institute

\section{Source}

National Cancer Institute. Teleprinter Device. NCI Thesaurus. Code C50213.

A character printer that transmits and receives text and data using telecommunications methods and operates like a typewriter. It has been largely replaced by high-speed data printers. 